\title{
Hereditary breast cancer: review and current approach
}

\author{
Cássio Furtini Haddad* (1)
}

\section{ABSTRACT}

Hereditary breast cancer is a complex and important condition, representing about $10 \%$ of all breast cancer cases. Identifying highrisk patients and possible carriers of pathogenic genetic variants with indication for genetic testing is an essential step to care for these patients and their families. Treatment can be influenced, both surgical and adjuvant, by the existence of mutation, providing the possibility of better results and preventive measures. In Brazil, access to oncogeneticists and genetic counseling is limited. Mastologists and their teams must be trained to identify and conduct the approach of these patients, with the objective of offering an adequate and preventive care, as well as early diagnostics. In the present study, a literature review of hereditary breast cancer aspects, diagnostic, and implications, in patients with and without breast cancer, was performed, aiming to assist in the proper management offered by mastologists, considering general and Brazilian characteristics.

KEYWORDS: breast cancer; genetic testing; heredity; mutation; genetic predisposition.

\section{INTRODUCTION}

Breast cancer (BC) is the most common cancer type affecting women worldwide. In Brazil, the National Cancer Institute (INCA) estimates more than 66,200 new cases for the triennial 2020-2022, corresponding to about $30 \%$ of all female cancers. ${ }^{1}$.

$\mathrm{BC}$ is known to be a heterogeneous disease, with different forms of presentation. Roughly $70 \%$ of all cases of $\mathrm{BC}$ are classified as sporadic, $20 \%$ as familial BC, and $10 \%$ as hereditary BC. Most of hereditary breast cancer (HBC) are due to variants in high penetrance genes, with early onset in premenopausal women and with an autossomal dominant heritage pattern. Familial BC has some similar aspects, but it often does not exhibit the dominant autossomal inheritance and the early appearence like in hereditary cases. In HBC, the individual is already born with one of the alleles containing a pathogenic variant, inherited from the father or mother, present in each cell of the body, leading to a greater predisposition to cancer. Most of the breast cancer susceptibility genes are suppressor genes, and there is germline mutation in high or moderate penetrance genes, with a $50 \%$ risk of transmitting the genetic alteration to the offspring.

Studies in molecular genetics demonstrate that cancer is a genetic illness due to inherited or acquired DNA mutations, which lead to oncogenes activation and/or supressor genes inactivation ${ }^{2}$. As mentioned, most $\mathrm{BC}$ predisposing genes are tumor suppressor genes, involved in DNA damage repair pathways and cell cycle control: BRCA1, BRCA2, TP53, PTEN, STK11, CDH1, CHEK2, ATM,
BRIP1, and PALB2. Mutations that occur in these genes are loss of function, and cause genomic instability and uncontrolled cell cycle, leading to uncontrolled proliferation of tumor cells ${ }^{3}$.

Carriers of genetic variants of susceptibility to BC are at increased risk of breast cancer and other tumors, both malignant and/or benign, and need to be identified, because this diagnosis has personal and family implications. In addition, $\mathrm{HBC}$ is frequently associated to unfavorable prognostic factors, especially in BRCAl-related carcinomas, such as high histological grade, angiolymphatic invasion, presence of basal cytokeratins and negative hormone receptors, which indicate a higher frequency of triple negative tumors when compared to sporadic carcinomas (60\%-80\% versus $15 \%-20 \%)^{4}$.

Original Knudson model is the most widely accepted for explaining many familial cancers, including breast cancer. With this model, the individual is already born with a genetic variant, and the second event (or second hit) occurs throughout life, usually at a younger age, which may be a mutation in the DNA or another mechanism of gene silencing. In hereditary cancers, the most common is a DNA mutation in the second allele, which may be a pontual mutation or an extensive deletion in the normal allele ${ }^{5}$.

Many aspects of $\mathrm{HBC}$ are still unknown. Even after the identification of moderate penetrance genes, a significantly number of patients with high family history for $\mathrm{BC}$ have no genetic variant known. Low penetrance genes have also been identified and have uncertain role in the scenario of HBC. Moreover, the same germline genetic mutation can present different forms of presentation 
(for example, age of onset and tumor characteristics), showing the presence of risk-modifying factors, capable of affecting the penetrancy and the expressiveness of the high-risk genetic variants.

Consequences of diagnosing a genetic mutation of risk for breast cancer should always be discussed before and after testing, involving, whenever possible, a multidisciplinary evaluation and a genetic counseling. Offering genetic counseling is still a complex issue in Brazil because oncogenetics are scarce and concentrated in large cities.

\section{METHODS}

Literature review was conducted by data base from PubMed, Scientific Electronic Library Online (SciELO), and Medical Literature Analysis, and Retrieval System Online (MEDLINE). The search was carried out during April and May 2020, using the terms breast cancer, hereditary breast cancer, genetic testing, hereditary presdisposition, BRCA mutation. Articles were selected by their title, year of publication, and scientific evidence. The search was limited to articles published in English. A total of 87 articles were preselected by their abstract or full text, and 64 articles were used to build the present study.

\section{RESULTS}

\section{Identifying high-risk patients for breast cancer} Identifyng high risk patients for $\mathrm{BC}$ is an important step in the medical practice. The definition of high risk includes women with a lifetime risk of developing the disease greater than $20 \%$, or a relative risk greater than four or five ${ }^{6,7}$. There are four situations that encompass this definition:

- personal history of atypical ductal hyperplasia or lobular neoplasia (atypical lobular hiperplasia and lobular carcinoma in situ);

- irradiation of the chest wall at a young age;

- strong family history without the presence of a genetic variant linked to hereditary cancer;

- carriers of genetic variants linked to hereditary cancer.

Risk measurement can be assessed with clinical history, heredrogram, risk prediction models, and genetic testing. $\mathrm{BC}$ risk calculation models mostly used in clinical practice and available on the internet are: Tyrer-Cuzick(IBIS Breast Cancer Risk Evaluation Tool; available on https://www.ems-trials.org/riskevaluator/), BOADICEA (Breast and Ovarian Analysis of Disease Incidence and Cancer Estimation Algorithm; available on https://www.ccge.medschl.com.ac.uk), BRCAPRO (available on https://www4.utsouthwestern.edu/breasthealth/cagene) and PENN II (available on https://pennmodel2. pmacs.upenn.edu/penn $2 /)^{8-10}$. Appropriate personal and family history are essential for guidance on the possibility of hereditary disease. Not every high-risk patient has characteristics of hereditary breast cancer. Then, assistant professionals must know how to identify high-risk patients to adopt the appropriate management and direct which patients at risk would have an indication for genetic testing.

Another way frequently used to identify a candidate for genetic testing is based on the guidelines of important scientific institutions or societies. Tables 1 and 2 show the National

Table 1. National Comprehensive Cancer Network (NCCN) criteria for genetic testing (modified for specific genes and hereditary cancer syndromes) - version 5.2020.

\begin{tabular}{|c|c|c|}
\hline \multicolumn{3}{|c|}{ NCCN 2020 - Genetic testing criteria } \\
\hline \multirow{9}{*}{$\begin{array}{l}\text { Personal } \\
\text { history of } \\
\text { breast cancer }\end{array}$} & Age $\leq 45$ & All patients \\
\hline & \multirow{3}{*}{ Age $46-50$} & $\begin{array}{l}\text { Unknown family history } \\
\text { A second breast cancer at any age }\end{array}$ \\
\hline & & $\begin{array}{l}\geq 1 \text { close relative with breast or } \\
\text { ovarian cancer at any age }\end{array}$ \\
\hline & & $\begin{array}{l}\geq 1 \text { close relative with prostate } \\
\text { cancer Gleason } \geq 7 \text { at any age }\end{array}$ \\
\hline & Age $\leq 60$ & Triple negative breast cancer \\
\hline & \multirow{4}{*}{ Any age } & Male breast cancer \\
\hline & & $\begin{array}{l}\geq 1 \text { relative with breast cancer with: } \\
\text { - Breast cancer } \leq 50 \text { years old } \\
\text { - Ovarian cancer } \\
\text { - Male breast cancer } \\
\text { - Prostate cancer Gleason } \geq 7 \\
\text { - Pancreatic cancer }\end{array}$ \\
\hline & & $\begin{array}{l}\geq 3 \text { total diagnoses of breast } \\
\text { cancer in patient and/or close } \\
\text { relatives }\end{array}$ \\
\hline & & Ashkenazi jewish ancestry \\
\hline \multirow{4}{*}{$\begin{array}{l}\text { Personal } \\
\text { history } \\
\text { of others } \\
\text { neoplasias }\end{array}$} & \multirow{4}{*}{ Any age } & Epithelial ovarian cancer \\
\hline & & $\begin{array}{l}\text { Metastatic prostate cancer } \\
\text { Gleason } \geq 7\end{array}$ \\
\hline & & Pancreatic cancer \\
\hline & & Ashkenazi Jewish ancestry \\
\hline \multirow{2}{*}{$\begin{array}{l}\text { Family history } \\
\text { of breast } \\
\text { cancer }\end{array}$} & & $\begin{array}{l}\text { Family with known pathogenic or } \\
\text { likely pathogenic variant }\end{array}$ \\
\hline & & $\begin{array}{l}1^{\text {st }} \text { or } 2^{\text {nd }} \text { degree relatives with } \\
\text { testing criteria }\end{array}$ \\
\hline \multirow{4}{*}{$\begin{array}{l}\text { Personal } \\
\text { history or } \\
\text { Family history } \\
\text { with } 3 \text { or more } \\
\text { members }\end{array}$} & & $\begin{array}{l}\text { Breast cancer, sarcoma, central } \\
\text { nervous system tumor and } \\
\text { leukemia (TP53) }\end{array}$ \\
\hline & & $\begin{array}{l}\text { Colon, endometrial, thyroid, and } \\
\text { kidney cancer, sings of Cowden } \\
\text { syndrome (PTEN) }\end{array}$ \\
\hline & & $\begin{array}{l}\text { Lobular breast cancer and gastric } \\
\text { cancer (CDH1) }\end{array}$ \\
\hline & & $\begin{array}{l}\text { Breast, gastrointestinal, } \\
\text { pancreatic, and sexual cord } \\
\text { cancer, signs of Peutz-Jeghers } \\
\text { syndrome (STK11) }\end{array}$ \\
\hline \multirow{2}{*}{$\begin{array}{l}\text { Regardless of } \\
\text { family history } \\
\text { of breast } \\
\text { cancer }\end{array}$} & \multirow[b]{2}{*}{ Any age } & $\begin{array}{l}\text { Test with alteration considered } \\
\text { eligible for target therapy }\end{array}$ \\
\hline & & $\begin{array}{l}\text { Pathogenic or likely pathogenic } \\
\text { variants of BRCA } 1 \text { or } 2 \text {, detected } \\
\text { in tumor genetic profile }\end{array}$ \\
\hline
\end{tabular}


Table 2. Brazilian Supplementary Health National Agency (Agência Nacional de Saúde Suplementar - ANS) criteria for genetic testing, 2018.

\begin{tabular}{|c|c|c|}
\hline \multicolumn{3}{|c|}{$\begin{array}{c}\text { Hereditary breast and ovarian cancer - GENES } \\
\text { BRCA1 and BRCA2 } \\
\text { National Supplementary Health Agency }\end{array}$} \\
\hline Coverage & & -iteria \\
\hline \multirow[b]{4}{*}{$\begin{array}{l}\text { 1. Mandatory coverage for women with } \\
\text { a current or previous diagnosis of breast } \\
\text { cancer when at least one of the following } \\
\text { criteria is met: }\end{array}$} & a. Diagnosis of breast cancer at age $\leq 35$; & - \\
\hline & $\begin{array}{l}\text { b. Diagnosis of breast cancer aged } \leq 50 \text {, } \\
\text { and one of the following criteria: }\end{array}$ & $\begin{array}{l}\text { I. a second primary breast tumor }(*) ; \\
\text { II. } \geq \text { one family member of } 1 s t, 2^{\text {nd }} \text { and } 3^{\text {rd }} \\
\text { degrees with breast and/or ovarian cancer; }\end{array}$ \\
\hline & $\begin{array}{l}\text { c. Diagnosis of breast cancer aged } \leq 60 \text { if } \\
\text { triple negative breast cancer (estrogen } \\
\text { receptor (ER), progesterone receptor } \\
\text { (RP) and HER2 receptor negative); }\end{array}$ & - \\
\hline & $\begin{array}{l}\text { d. Diagnosis of breast cancer at any age } \\
\text { plus one of the following: }\end{array}$ & $\begin{array}{l}\text { I. } \geq \text { one family member of } 1^{\text {st }}, 2^{\text {nd }} \text {, and } 3^{\text {rd }} \\
\text { degrees with female breast cancer aged } \leq 50 ; \\
I I . \geq \text { one family member of } 1^{\text {st }}, 2^{\text {nd, }} \text { and } 3^{\text {rd }} \\
\text { degrees with male breast cancer at any age; } \\
\text { III. } \geq \text { one family member of } 1^{\text {st }}, 2^{\text {nd }} \text {, and } 3^{\text {rd }} \\
\text { degrees with ovarian cancer at any age; } \\
\text { IV. } \geq \text { two relatives of } 1^{\text {st }}, 2^{\text {nd }}, \text { and } 3^{\text {rd }} \text { degrees on } \\
\text { the same side of the family with breast cancer } \\
\text { at any age; } \\
\text { V. } \geq 2 \text { relatives of } 1^{\text {st }}, 2^{\text {nd }}, \text { and } 3^{\text {rd }} \text { degrees on } \\
\text { the same side of the family with pancreatic or } \\
\text { prostate cancer (Gleason score } 7 \text { ) at any age. } \\
\left(^{*}\right)(*) \text { In the case of bilateral breast cancer or } \\
\text { two primary neoplasms in the same breast } \\
\text { (confirmed by anatomopathological reports), } \\
\text { each of the tumors must be considered } \\
\text { independently. }\end{array}$ \\
\hline $\begin{array}{l}\text { 2. Mandatory coverage for women with a } \\
\text { current or previous diagnosis of ovarian } \\
\text { cancer (epithelial tumor) at any age and } \\
\text { regardless of family history. }\end{array}$ & - & - \\
\hline $\begin{array}{l}\text { 3. Mandatory coverage for men with a } \\
\text { current or previous diagnosis of breast } \\
\text { cancer at any age and regardless of family } \\
\text { history. }\end{array}$ & - & - \\
\hline $\begin{array}{l}\text { 4. Mandatory coverage for patients with } \\
\text { pancreatic cancer and } \geq \text { two relatives of } \\
1^{\text {st }}, 2^{\text {nd }} \text {, and } 3^{\text {rd }} \text { degrees on the same side of } \\
\text { the family with breast and/or ovarian and/ } \\
\text { or pancreatic or prostate cancer (Gleason } \\
\text { score } \geq 7 \text { ) at any age. }\end{array}$ & - & - \\
\hline $\begin{array}{l}\text { 5. Mandatory coverage for patients with } \\
\text { prostate cancer (Gleason score } \geq 7 \text { ) and } \\
\geq \text { two relatives of } 1^{\text {st }}, 2^{\text {nd }}, \text { and } 3^{\text {rd }} \text { degrees } \\
\text { on the same side of the family with breast } \\
\text { and/or ovarian and/or pancreatic or } \\
\text { prostate cancer (score of Gleason } \geq 7 \text { ) at } \\
\text { any age. }\end{array}$ & - & - \\
\hline $\begin{array}{l}\text { 6. Mandatory coverage for testing the } \\
\text { t founding Ashkenazi mutations in the } \\
\text { BRCA1 and BRCA2 genes in patients of } \\
\text { Ashkenazi Jewish origin when at least one } \\
\text { of the following criteria is met: }\end{array}$ & $\begin{array}{l}\text { a. breast cancer at any age and regardless } \\
\text { of family history; } \\
\text { b. ovarian cancer at any age and } \\
\text { regardless of family history; } \\
\text { c. pancreatic cancer at any age with } \geq \\
\text { one family member of the } 1^{\text {st }}, 2^{\text {nd }}, \text { and } 3^{\text {rd }} \\
\text { degrees with breast, ovarian, pancreatic } \\
\text { or prostate cancer (Gleason score } \geq 7 \text { ). }\end{array}$ & - \\
\hline
\end{tabular}


Table 2. Continuation.

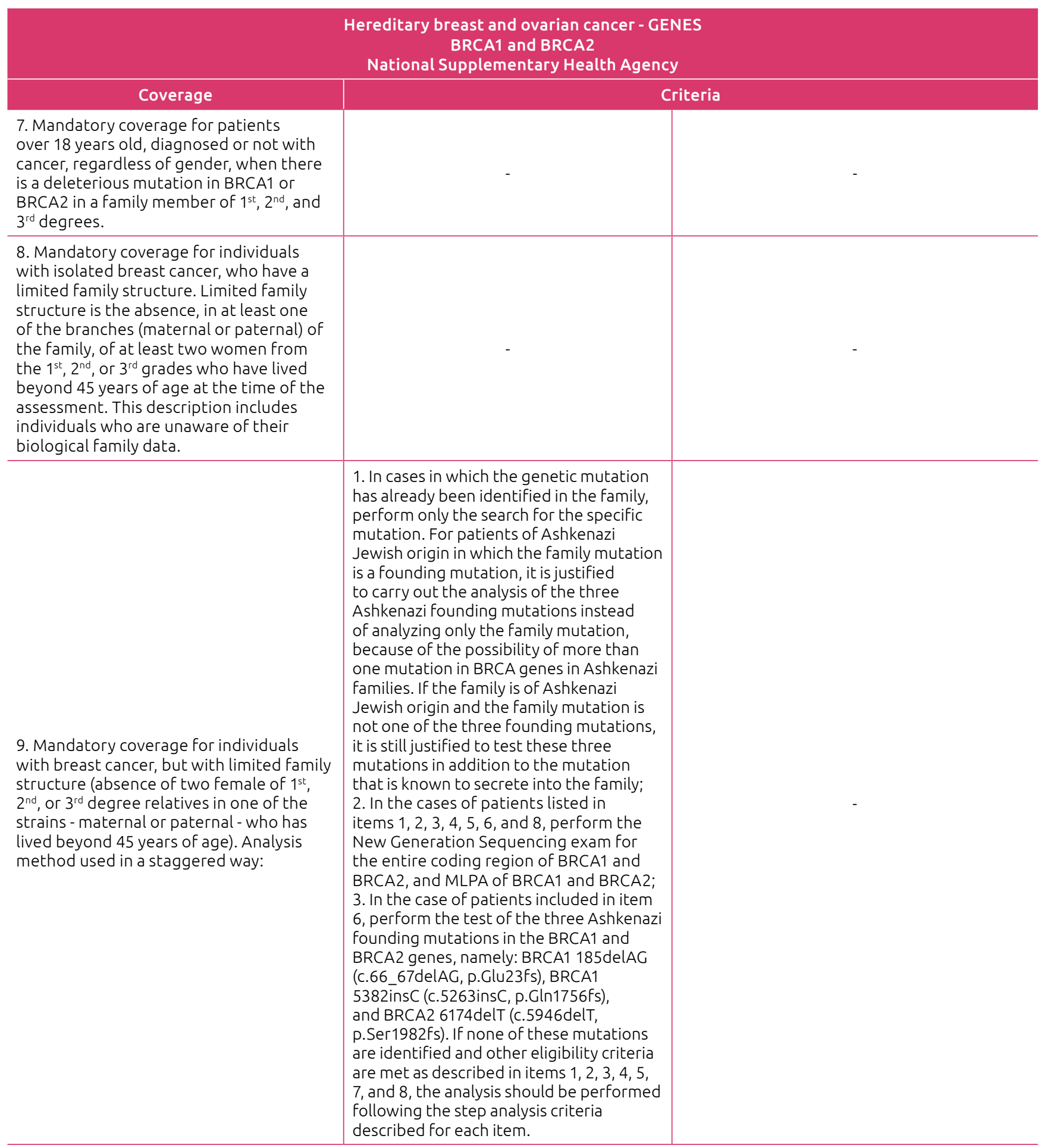

Comprehensive Cancer Network (NCCN) and the Brazilian National Supplementary Health Agency (Agência Nacional de Saúde - ANS) criteria for genetic testing, respectively.

Recently, the American Society of Breast Surgeons (ASBS) reviewed its consensus guidelines and recommended that genetic testing should be available to all patients with a personal history of BC. Recommendations were based on identification of pathogenic genetic variants as influencing patient management in terms of high-risk screening and risk-reduction approach, as well as specific therapeutics options related to surgery, 
radiotherapy, and systemic treatment ${ }^{11}$. Moreover, Beitsch et al., in a multicenter prospective registry study with 959 patients, concluded that approximately $45 \%$ of patients with BC with clinically actionable germline variants are left out when testing is restricted to patients meeting current NCCN guidelines and when testing strategies are limited to painels containing only BRCA1 $/ 2^{12}$.

\section{Genetic tests for hereditary predisposition to cancer}

Genetic tests to identify BC susceptibility genes are indicated when there is clinical suspicion, usually after heredrogram, risk prediction models, or specific guidelines. Before testing, patients need to be made aware of the implications that test results can have (pre-test counseling). When results become available, patients should be reminded of these implications and be provided the appropriate clinical context for the results to make informed decisions (post-test counseling). All genetic testing should be performed in the setting of informed consent. Knowing that not all carriers of patogenic genetic variants will develop $\mathrm{BC}$ is also importante. On the other hand, a negative test result does not necessarilly imply the absence of risks.

In general, when family history is suggestive, the best scenario is to test the individual with a cancer diagnosis, because this increases the probability of a positive result. For multiple affected individuals, the preference is to start testing the youngest individual.

Genetic testing for germline variants can be done with a blood sample (analyzing leukocyte DNA samples) or an oral mucosa/saliva sample (analyzing epithelial cells).

In practice, three main types of tests are used: the first generation of genetic sequencing using the Sanger technique was considered the gold standard for research pontual mutations for a long time. It is an accurate, but laborious and expensive method, that needs large amounts of DNA and examines individual fragments of the gene of interest to a single patient at a time ${ }^{13}$. Its limitation is not detecting large rearrangements in DNA. Secondary analysis found that $6 \%-18 \%$ of individuals who are BRCA mutation negative by this technique can be explained by large insertions and deletions in the BRCA1 and BRCA2 genes, detected using other new technology ${ }^{14}$. Currently, its use is restricted to situations in which a certain mutation in the family is already known and has the desire to research it. The Next Generation Sequency (NGS) technique can analyze multiple genes simultaneously, which optimizes costs and is the current preference. However, it has a low sensitivity for large insertions/deletions and can found an expressive finding of variants of uncertain significance (VUS ${ }^{15,16}$. These multigenic panels can encompass high and moderate penetration genes. NGS has been recently updated to detect copy numbers alterations (CNA), with highly confident detection rates. Another technique is the Multiplex Ligation-dependent
Probe Amplification (MLPA), a multiplex PCR method developed to detect abnormal copy numbers of different genomic DNA sequences, not rarely used to complement diagnostic research and identify major deletions, especially in BRCA1, BRCA2, and TP53 genes. Most of the pathogenic genetic variants in the BRCA genes are punctual and detected by the Sanger technique or NGS multigenic panels, but data show up to $12 \%$ of changes in these genes are due to deletions detected by MLPA ${ }^{17}$.

Currently, most genetic studies are carried out by multigenic panels with NGS platforms, complemented, when needed, by the MLPA technique, mainly in cases of strong family suspicion and negative panel results.

The possible results of a genetic test are:

- class 1: benign variant;

- class 2: likely benign variant;

- class 3: variant of uncertain significance (VUS);

- class 4: likely pathogenic variant;

- class 5: pathogenic variant.

Table 3 shows the genetic testing results and interpretation. VUS should always be reported and periodically reassessed. Most VUS will be reclassified into benign or likely benign categories.

\section{Hereditary breast cancer susceptibility genes}

Genetic biomarkers of cancer risk can be categorized into two primary criteria: penetrance and population frequency. Penetrance refers to the estimate that a specific condition, in this case cancer, will occur in the presence of a specific genotype. It refers to the probability, in percentage, to express typical phenotypes at specific timepoints.

The Human Genome Variation Society (HGVS) developed an internationally accepted nomenclature that recommends the use of the neutral term variant rather than mutation. Risk variants mostly show an inversely proportional impact, from very rare ones, with high penetrance, to the common low-risk single nucleotide variants, with high allele frequency (of up to $50 \%$ ):

Table 3. Results and interpretation of genetic testing for cancer predisposition.

\begin{tabular}{|c|c|}
\hline Result & Interpretation \\
\hline True positive & $\begin{array}{l}\text { Carrier of a cancer predisposition variant that } \\
\text { is already known and present in the family. }\end{array}$ \\
\hline True negative & $\begin{array}{c}\text { Individual does not carry a known cancer } \\
\text { predisposing gene that has been identified in } \\
\text { another family member. }\end{array}$ \\
\hline Indeterminate & $\begin{array}{l}\text { Individual does not carry a known gene } \\
\text { for cancer predisposition and the status of } \\
\text { another family member is unknown. }\end{array}$ \\
\hline $\begin{array}{l}\text { Inconclusive } \\
\text { (VUS) }\end{array}$ & $\begin{array}{c}\text { Carrier of a mutation in a gene that currently } \\
\text { has unknown clinical significance. }\end{array}$ \\
\hline
\end{tabular}

VUS: variants of uncertain significance. 
- High-risk variants: very rare in the population with a minor allele frequency $<0.005$. The conferred relative risk of breast cancer is higher than 4 ;

- Moderate-risk variants: rare, with a minor allele frequency of 0.005-0.01. Pathogenic variants confer a relative risk of 2-4;

- Low-risk variants: minor allele frequency $>0.01$, and conferred risk of breast cancer of less than 1.5-time ${ }^{18}$.

The number of cases in which BC resulted from genetic polymorphisms and genes with low-penetrance (regarding environmental interactions) is considerably larger than the number of $\mathrm{BC}$ cases resulted from mutations of high penetrance genes. In the HBC scenario, most cases are due to BRCA1 and BRCA2 variants, whereas others genes are responsible for about $40 \%$ of all cases (Figure 1).

\section{High-penetrance genes}

\section{BRCA1 and BRCA2}

The first major gene associated to $\mathrm{HBC}$ was the BRCA1, located on chromosome 17q21, and identifyed in 1990 with linkage analysis in families with suggestive pedigrees ${ }^{19}$. In 1994, BRCA2 gene, located on chromosome 13q12-13, was also identifyed. They have an autosomal dominant inheritance pattern.

BRCA1 and BRCA2 (BRCA1/2) mutations confer a very high life-time risk of $\mathrm{BC}$ in the range of $50 \%-85 \%$ for $\mathrm{BRCA} 1$, and up to $45 \%$ for BRCA $2^{20}$. The risk of ovarian cancer (OC) is also higher: $30 \%-60 \%$ for BRCA1, and $10 \%-25 \%$ for BRCA 2 carri$\mathrm{ers}^{21}$. A greater incidence of other cancers is documented such as prostate, pancreatic, fallopian tube, and primary peritoneal adenocarcinoma for both BRCA1/2 genes, and male BC and melanoma for BRCA2 gene.

Most BRCA1-related breast cancers have a basal-like phenotype and they are also characterized by the lack of expression of estrogen-receptors, progesterone-receptors, and of no overexpression of human epidermal growth factor 2 (triple negative BC). In addition, over-expression of the epidermal growth

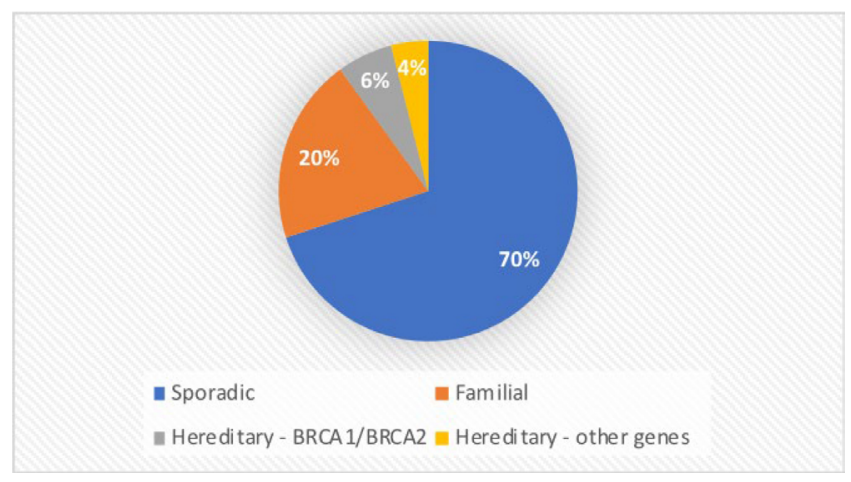

Figure 1. Breast cancer classification by cause. fator receptor (EGFR) has been associated to BRCA1-related breast cancers $^{22}$. The immunophenotype and gene expression profile of BRCA2-related cancers are very similar to sporadic breast cancers, with a predominance of positive hormone receptor tumors (luminal BC). Both BRCA1 and BRCA2 tumors exhibit a higher histological grade; BRCA1 tumors are more often poorly differentiated (Grade 3), whereas BRCA2 tumors more frequently are moderately or poorly differentiated (Grades 2 and 3$)^{23}$. The majority of BRCA1 and BRCA2-associated ovarian cancers are classified as high-grade serous carcinomas.

In terms of surveillance, an annual breast nuclear magnetic resonance (MRI) in conjunction with annual mammography screening in BRCA1 and BRCA2 carriers from the age of 30 years is more sensitive than annual mammography alone, detecting $\mathrm{BC}$ at an earlier stage ${ }^{24-26}$. Moreover, lifestyle changes and risk reduction strategies should be discussed. Trials involving chemoprevention with Tamoxifen $20 \mathrm{mg}$ once a day for five years have demonstred that BC risk can be reduced by $40 \%-50 \%$ in women at high risk, although not necessarialy in pathogenic variant carriers ${ }^{27}$. Whereas BRCA1 BC are predominantly estrogen receptor (ER) negative and BRCA2 BC are predominantly ER positive, and considering that data are limited regarding the benefit of Tamoxifen in BRCA carriers, Tamoxifen use may be an option for patients who do not want to udergo risk-reducing surgery ${ }^{28,29}$. Risk-reducing bilateral mastectomy should be discussed, and literature shows more than $90 \%$ reduction in the BC incidence $^{30}$. A recent study showed that bilateral risk-reducing mastectomy in mutation carriers had an impact on mortality in BRCA1 carriers, although the impact in BRCA2 carriers was less evident $^{31}$. Nipple-sparing mastectomy is a safe and appropriate technique to be evaluated, according to breast size, tumor localization, and degree of ptosis. In addition, prophylactic salpingooophorectomy (PSO) confers a $72 \%-88 \%$ risk reduction in OC and fallopian tubal cancer. Literature data show PSO confers a reduction in OC-specific and all-cause mortality in BRCA carriers $^{31-33}$. Therefore, PSO is recommended for BRCA carriers who have completed childbearing, and it should be performed by age 35-40 in BRCA1 carriers, and by age 40-45 in BRCA2 carriers $^{31}$. Early surgical castration causes early menopause and increases the risk of cardiovascular disease and osteoporosis. On the basis of available data from observational studies, hormone replacement therapy after PSO should not be performed in patients affected by BC, but it has not shown an increased risk of BC among cancer-free BRCA carriers who have undergone risk-reduction bilateral mastectomy ${ }^{34}$.

After a $\mathrm{BC}$ diagnosis, surgical approach must be individualized and well debated with patients. According to the recent guidelines by the American Society of Clinical Oncology (ASCO), American Society for Radiation Oncology (ASTRO), and Society of Surgical Oncology (SSO) both breast conservative therapy (BCT) and mastectomy are possible ${ }^{35}$. Observational studies suggest 
$\mathrm{BCT}$ is a safe surgical option for managing $\mathrm{BC}$ in BRCA carriers. However, BRCA 1/2 carriers should be informed about the risk of contralateral breast cancer $(\mathrm{CBC})$ and a possible increased risk of a new primary cancer in the ipsilateral breast when compared to noncarriers. Cumulative $\mathrm{CBC}$ risk 20 years after a first primary $\mathrm{BC}$ is $40 \%$ for BRCA1 and $26 \%$ for BRCA2 carriers. Current evidence suggests that contralateral risk-reducing mastectomy is effective for BRCA1 carriers, reducing mortality ${ }^{32,36}$. The benefit of contralateral prophylactic mastectomy depends, however, on the previous or current tumor prognosis, age of patient and clinical conditions for the procedure. Recently, van den Broek et al, when comparing BCT versus mastectomy in BRCA mutation carriers to noncarriers, found low local recurrence rates, similar overall survival, and no difference in local recurrence rate ${ }^{37}$.

Radiotherapy-related toxicity in patients with breast cancer with BRCA1/2 variants showed that rates of radiation-associated complications in women with BRCA1/2 variants were comparable to rates observed in women with sporadic breast cancer ${ }^{38,39}$.

Two phase III trials (OlympiAD and EMBRACA) randomly assigned patients after chemotherapy in HER2-negative, $\mathrm{BRCA}$-associated metastatic $\mathrm{BC}$, and showed longer progressionfree survival with PolyADP-Ribose Polymerases (PARP) inhibitor ${ }^{40,41}$. The Food and Drug Administration has approved 2 PARP inhibitors (Olaparib and Talazoparib) for germline BRCA-associated metastatic BC. In Brazil, Olaparib was approved in this setting by the Brazilian Health Regulatory Agency (Agência Nacional de Vigilância Sanitária - ANVISA) in $2018^{42}$.

\section{TP53}

One of the most studied tumor supressor gene is the tumor protein 53 (TP53), located on chromosome 17p13.1. Inherited TP53 mutatins are associated to the rare autossomal dominant disorder, the Li Fraumeni Syndrome (LFS). Female variant carriers have a nearly $100 \%$ lifetime risk of cancer compared to $73 \%$ for males, difference which is caused by $\mathrm{BC}^{43}$. Unlike other high-risk genes that mostly display risk associated to truncating mutations, genotype-phenotype analysis in LFS families has revealed that germline missense mutations are more frequent. Other than breast cancer in women, TP53 variant carriers are at increased risk of early-onset and multiple primary cancers, including sarcomas, brain, and adrenocortical tumors. Lymphoma, leukemia, melanoma, lung, pancreatic, prostate, and ovarian cancers also seem to be more frequent. Childhood-onset tumors exists, and the most common are brain tumors, followed by sarcomas ${ }^{44,45}$.

In Brazil, because of the founder variant present in a significant part of the population, especially in the Southern region, appropriate investigation and management are therefore important. Recently, a TP53 mutation called p.R337H is drawing the attention of professionals who deal with breast cancer, as it has been identified in a significant portion of patients ${ }^{46}$.
Carriers of a TP53 pathogenic variant should receive intensive surveillance. Breast MRI should be offered annually from age 20 , as well as mammography after age 30 . Risk-reducing bilateral mastectomy in patients without $\mathrm{BC}$ and contralateral risk-reducing mastectomy in patients with $\mathrm{BC}$ should be suggested ${ }^{43}$.

TP53 gene may be the most critical tumor suppressor gene in preventing the development of cancer. It plays an important role in cell cycle control and apoptosis, and provides the cell with the ability to respond to and repair DNA damage after cellular stress by triggering multiple downstream repair pathways. Thus, carriers of a TP53 variant would be expected to be unable to repair tissue damage from DNA-damaging RT and be at risk for significant RT-associated sequelae. For these reasons, there is limited evidence to inform the clinical question of the role of RT in women who carry a TP53 mutation. Outcomes reported in published case reports support this recommendation against $\mathrm{RT}$ in women with breast cancer who carry a TP53 variant ${ }^{47,48}$. Thus, mastectomy is the recommended therapeutic option.

Based on Toronto protocol, whole-body MRI and brain MRI should be performed at the first preventive clinical screening evaluation in TP53 carriers of pathogenic germline variants, because of the high risk of sarcomas and central nervous system, adrenocortical, and other tumors ${ }^{49}$. However, due to the Brazilian social and economic reality, and the limited assess of most citizens to these technologies, feasibility of this recommendation is hard to be adopted.

\section{PTEN}

Cowden syndrome is a rare condition caused by germline mutations in tumor suppressor gene PTEN, located on chromosome 10q23.31. Studies of carriers of disease-causing variants show a considerably high lifetime risk of breast cancer, with low age of onset. Carriers are also at an increased risk of several other malignancies, especially thyroid and endometrial cancer. The syndrome is otherwise characterized by multiple hamartomas of the gastrointestinal tract, macrocephaly, and benign tumors, such as lipomas ${ }^{50}$.

Surveillence with clinical breast examination since age 25, and annual MRI and mammography starting between 30 and 35 years of age is recommended. Risk-reducing mastectomy is controversial, but it can be considered due to the risk of up to $85 \%$ by the age of 75 in women ${ }^{51}$.

\section{$\mathrm{CDH} 1$}

The CDH1 gene, located on chromosome 16q22.1, encodes a protein responsible for cell-to-cell adhesion and functions as a cell invasion supressor ${ }^{52}$. E-cadherin germline mutations are responsible for hereditary diffuse gastric cancer (HDGC). Carriers of truncating variants are at a very high risk of diffuse 
gastric carcinoma at young age and, in addition, an estimated relative risk of breast cancer of 6.6 (predominantly lobular breast cancer $)^{53}$. Recent studies have provided evidence of lobular breast cancer as the first manifestation of HDGC. Deleterious CDH1 mutations have been identified in women with bilateral lobular breast cancer without a family history of diffuse gastric cancer. The risk of colorectal cancer also appears to be increased ${ }^{54}$.

MRI screening, in women with or without mammography, started at 30 years of age, is the current recommendation for $\mathrm{CDH} 1$ mutation carriers. Although evidence is limited, prophylactic mastectomy can be discussed, especially when a family history of $\mathrm{BC}$ is present ${ }^{55}$.

Prophylactic partial gastrectomy can be indicated as a preventive measure, given that the risk of gastric cancer reaches $67 \%$ in men and $83 \%$ in women ${ }^{56}$.

\section{STK11}

The tumor suppressor STK11, located on chromosome 19p13.3, is another gene with a gene product important for cell cycle regulation and mediation of apoptosis. Deleterious mutations cause Peutz-Jeghers Syndrome, characterized by intestinal hamartomous polyps and mucocutaneous pigmentation. In addition, the lifetime risk of breast cancer by 60 years old is $32 \%-54 \%^{57}$. Other associated tumors with markedly elevated risk are cancers of gastrointestinal origin and pancreatic cancer. Female carriers are also at an increased risk of ovarian sex cord-stromal tumors and a rare tumor of the cervix, the adenoma malignum. Carriers of STK11 mutations have a cumulative lifetime risk of any cancer of up to $85 \%^{57}$.

Breast clinical examination associated to MRI and mammography from the age 25 is recommended ${ }^{58}$. Prophylactic mastectomy, oophorectomy, and histerectomy are controversial procedures, but they can be discussed individually ${ }^{59}$.

\section{Moderate penetrance genes}

Studies have identified several additional DNA repair genes that interact with BRCA genes and confer an approximate twofold increase in BC risk, including CHEK2, ATM, and PALB2 ${ }^{60}$. NBN and NF1 genes are also genes of moderate penetration with increased risk of breast cancer ${ }^{61}$. Recently, BARD1, RAD51D, and MSH6 were identified as moderate-penetrance genes.

The lifetime risk of BC associated to a variant in PALB2 is approximately from $35 \%$ to $60 \%$, whereas with ATM and truncating CHEK2 mutations lifetime risk is from $25 \%$ to $30 \%^{62}$. In a meta-analysis, loss-of-function PALB2 variants have yielded a combined estimated relative risk for $\mathrm{BC}$ of 5.3 in carriers of pathogenic mutations, which suggests that PALB2 should, instead, be possibly placed in the high-risk category ${ }^{63}$.

According to the recent guidelines by ASCO, ASTRO, and SSO moderate genes mutation carriers should undergo high-risk breast screening with annual MRI and mammogram. Mutation status alone should not determine local therapy decisions, and BCT should be offered when it is an appropriate option. Evidence regarding contralateral $\mathrm{BC}$ is limited. Contralateral prophilactic mastectomy decision should not be based predominantly on mutation status ${ }^{35}$.

\section{DISCUSSION}

The identification of high-risk patients for $\mathrm{BC}$ is crucial for the current clinical management. Likewise, suspecting patients liable to carry a hereditary genetic mutation at risk for $\mathrm{BC}$ and other neoplasms has become an important measure in healthcare, with personal and family impacts. Considering that roughly $10 \%$ of $\mathrm{BC}$ cases are hereditary, one in 10 cases have an inherited genetic component to be detected. Worldwide, there is a sub-identification of cancer susceptibility mutations. Population-based approaches to genomic screening remain costly and involve challenges in high through-put sequencing, obtaining informed consent, correct interpretation of genomic variants, and posttest implications ${ }^{64}$.

In Brazil, the limitation of access to oncogeneticists and genetic tests is a real issue and clearly needs improvement. There is an evident gap in this assessment, especially in the public health system, but also in supplementary health. Access to genetic test must involve a multidisciplinary team, with pre and post-test counseling and individual discussion case-by-case, both in the positive and negative scenario for genetic mutation. $\mathrm{HBC}$ approach involves integration between indication, application, and understanding of germline testing. For this, based on the ASBS recommendations on its last consensus guidelines, the training and betterment of mastologist doctors should be encouraged $^{11}$. Cancer genetics knowledge allows mastologists to initiate and guide genetic testing for their patients. Strategies related to public awareness, education, integrated services, telemedicine, and multidisciplinar approach are needed.

An appropriate screening strategy and the discussion of risk-reducing measures must be offered. Any patient found to have a hereditary predisposition for BC should be informed of all options to reduce their risk: lifestyle changes, chemoprevention, and risk-reducing surgeries.

The recent guidelines by ASCO, ASTRO, and SSO brought an updated guide for both HBC driving and management. According to it, evidence support prophylactic mastectomy for BRCA1, BRCA2, and TP53 mutation carriers ${ }^{35}$. For the other high penetration genes, evidence is poor, with no clear basis for prophylactic surgery, as well as for moderate penetrance genes ${ }^{35}$. Surgical management of BC in a pathologic variant carrier must consider age, clinical condition, staging at diagnosis and can include both BCT and mastectomy with oncological safe. However, the risk of a new primary tumor 
in the breast treated with conservative surgery appears to be greater. Contralateral mastectomy is an option, especially for the therapeutic mastectomy candidates, and should be considered according to the prognostic associated to the the primary cancer. Likewise, RT is safe and an important adjuvant treatment, except in those with TP53 variant, in which the risk of radio-induced tumors is high ${ }^{35}$. Finally, in the systemic treatment, evidence suggest that for germline BRCA1/2 mutation carrier with metastatic BC, platinum chemotherapy is preferred rather than taxane therapy for patients who have not previously received platinum. There are no data to address platinum efficacy in other germline mutation carriers ${ }^{35}$. For BRCA1/2 mutation carriers with metastatic HER2-negative BC, Olaparib or Talazoparib (oral drugs) should be offered as an alternative to chemotherapy in the first- to third-line settings. In Brazil, Olaparib is approved by ANVISA since 2018. For BRCA1/2 mutation carriers with metastatic HER2-negative
$\mathrm{BC}$, there are no data directly comparing efficacy of PARP inhibitors to platinum chemotherapy ${ }^{35}$.

\section{CONCLUSIONS}

HBC is still a complex disease, with a wide field of approach to be explored, from the suspicion and identification of individuals and families with pathogenic variants, with the adoption of riskreducing measures and specific therapies in those who develop cancer. Strategies to improve this identification must be developed, refined, and disseminated.

Mastologists and their multidisciplinary team must be trained in the approach of $\mathrm{HBC}$ to facilitate the access of carriers to educational and investigative processes.

The appropriate treatment after the diagnosis of an $\mathrm{HBC}$ can offer better results and be cost-effective in terms of disease control and preventive measures.

\section{REFERENCES}

1. Brasil. Ministério da Saúde. DATASUS. Estatísticas vitais [Internet]. Brasília: Ministério da Saúde; 2020 [accessed on May 1, 2020]. Available at: https://www.inca.gov.br/numerosde-cancer

2. Levine EG, King RA, Bloomfiel CD. The role of heredity in cancer. J Clin Oncol. 1989;7(4):527-40. https://doi.org/10.1200/ jco.1989.7.4.527

3. Walsh T, King MC. Ten genes for inherited breast cancer. Cancer Cell. 2007;11(2):103-5. https://doi.org/10.1016/j. ccr.2007.01.010

4. Kenney MG, Couch FJ, Visscher DW, Lindor NM. Non-BRCA familial breast cancer: review of reported pathology and molecular findings. Pathology. 2017;49(4):363-70. https://doi. org/10.1016/j.pathol.2017.03.002

5. Maxwell KN, Wubbenhorst B, Wenz BM, De Sloover D, Pluta J, Emery L, et al. BRCA locus-specific loss of heterozygosity in germline BRCA1 and BRCA2 carriers. Nat Commun. 2017;8(1):319. https://doi.org/10.1038/s41467-017-00388-9

6. National Cancer Institute. Portal [Internet]. NCI; 2019 [accessed on May $\left.1^{\text {st }}, 2020\right]$. Available at: http://www.cancer.gov

7. Constantino JP, Gail MP, Pee D, Anderson S, Redmond CK, Benichou J, et al. Validation studies for models projecting the risk of invasive and total breast cancer incidence. J Natl Cancer Inst. 1999;91(18):1541-8. https://doi.org/10.1093/jnci/91.18.1541

8. Cuzick J. A breast cancer prediction model incorporating familial and personal risk factors. Hered Cancer Clin Pract. 2012;10(Suppl. 2):A29. https://doi.org/10.1186/1897-4287-10S2-A29

9. Antoniou AC, Hardy R, Walker L, Evans DG, Shenton A, Eeles A, et al. Predicting the likelihood of carrying a BRCA 1 or BRCA 2 mutation: validation of BOADICEA, BRCAPRO, IBIS,
Myriad and the Manchester scoring system using data from UK genetics clinics. J Med Genet. 2008;45(7):425-31. https:// doi.org/10.1136/jmg.2007.056556

10. Parmigiani G, Chen S, Iversen ES, Friebel TM, Finkelstein DM, Ziogas A, et al. Validity of models for predicting BRCA 1 and BRCA 2 mutations. Ann Intern Med. 2007;147(7):441-50. https://doi.org/10.7326/0003-4819-147-7-200710020-00002

11. Manahan ER, Kuerer HM, Sebastian M, Hughes KS, Boughey JC, Euhus DM, et al. Consensus Guidelines on Genetic Testing for Hereditary Breast Cancer from the American Society of Breast Surgeons. Ann Surg Oncol. 2019;26(10):3025-31. https:// doi.org/10.1245/s10434-019-07549-8

12. Beitsch PD, Whitworth PW, Hughes K, Patel R, Rosen B, Compagnoni G, et al. Underdiagnosis of Hereditary Breast Cancer: are genetic testing guidelines a tool or na obstacle? J Clin Oncol. 2019;37(6):453-60. https://doi.org/10.1200/ jco.18.01631

13. Thomas E, Mohammed S. Advances in Genetic Testing for Hereditary Cancer Syndromes. In: Pitchert G, Jacobs C (eds.). Rare Hereditary Cancers. Cham: Springer; 2016. p. 1-16. https:// doi.org/10.1007/978-3-319-29998-3_1

14. Palma MD, Domchek SM, Stopfer J, Erlichman J, Siegfried JD, Mason BA, et al. The relative contribution of point mutations and genomic rearrangements in BRCA 1 and BRCA 2 in highrisk breast cancer families. Cancer Res. 2008;68(17):7006-14. https://dx.doi.org/10.1158\%2F0008-5472.CAN-08-0599

15. Walsh T, Casadei S, Lee MK, Pennil CC, Nord AS, Thornton AM, et al. Mutations in 12 genes for inherited ovarian, fallopian tube, and peritoneal carcinoma identified by massively parallel sequencing. Proc Natl Acad Sci USA. 2011;108(44):18032-7. https://doi.org/10.1073/pnas.1115052108 
16. Kurian A, Hughes E, Hanford EA, Gutin A, Allen B, Hartman A-R, et al. Breast and ovarian cancer penetrance estimated derived from germline multiple-gene sequencing results in women. JCO Precis. 2017;1:1-12. https://doi.org/10.1200/PO.16.00066

17. Walsh T, Casadei S, Coats KH, Swisher E, Stray SM, Higgins J, et al. Spectrum of mutations in BRCA 1, BRCA 2, CHEK 2, and TP53 in families at hight risk of breast cancer. JAMA. 2006;295(12):1379-88. https://doi.org/10.1001/jama.295.12.1379

18. Mavaddat N, Antoniou AC, Easton DF, Garcia-Closas M. Genetic susceptibility to breast cancer. Mol Oncol. 2010;4(3):174-91. https://doi.org/10.1016/j.molonc.2010.04.011

19. Hall JM, Lee MK, Newman B, Morrow JE, Anderson LA, Huey B, et al. Linkage of early-onset familial breast cancer to chromosome 17q21. Science. 1990;250(4988):1684-89. https:// doi.org/10.1126/science.2270482

20. Kuchenbaecker KB, Hopper JL, Barnes DR, Phillips KA, Mooij TM, Roos-Blom MJ, et al. Risks of breast, ovarian, and contralateral breast cancer for BRCA1 and BRCA2 mutation carriers. JAMA. 2017;317(23):2402-16. https://doi.org/10.1001/jama.2017.7112

21. Ford D, Easton DF, Stratton M, Narod S, Goldgar D, Devilee $\mathrm{P}$, et al. Genetic heterogeneity and penetrance analysis of the BRCA1 and BRCA2 genes in breast cancer families. The Breast Cancer Linkage Consortium. Am J Hum Genet. 1998;62(3):67689. https://doi.org/10.1086/301749

22. van der Groep P, Bouter A, van der Zanden R, Menko FH, Buerger $\mathrm{H}$, Verheijen $\mathrm{RH}$, et al. Re: germline BRCA1 mutations and a basal epithelial phenotype in breast cancer. J Natl Cancer Inst. 2004;96(9):712-3; author reply 714. https://doi. org/10.1093/jnci/djh114

23. van der Groep P, van der Wall E, van Diest PJ. Pathology of hereditary breast cancer. Cell Oncol. 2011;34(2):71-88. https:// dx.doi.org/10.1007\%2Fs13402-011-0010-3

24. Kuhl C, Weigel S, Schrading S, Arand B, Bieling H, Konig H, et al. Prospective multicenter cohort study to refine management recommendations for women at elevated familial risk of breast cancer: The EVA trial. J Clin Oncol. 2010;28(9):1450-7. https:// doi.org/10.1200/jco.2009.23.0839

25. Riedl CC, Luft N, Bernhart C, Weber M, Bernathova M, Tea MKM, et al. Triple-modality screening trial for familial breast cancer underlines the importance of magnetic resonance imaging and questions the role of mammography and ultrasound regardless of patient mutation status, age, and breast density. J Clin Oncol. 2015;33(10):1128-35. https://doi. org/10.1200/jco.2014.56.8626

26. Saslow D, Boetes C, Burke W, Harms S, Leach MO, Lehman CD, et al. American Cancer Society guidelines for breast screening with MRI as an adjunct to mammography. CA Cancer J Clin. 2007;57(2):75-89. https://doi.org/10.3322/canjclin.57.2.75

27. Cuzick J, Sestak I, Bonanni B, Constantino JP, Cummings S, DeCensi A, et al. Selective oestrogen receptor modulators in prevention of breast cancer: An updated meta-analysis of individual participant data. Lancet. 2013;381(9880):1827-34. https://doi.org/10.1016/s0140-6736(13)60140-3

28. King MC, Wieand S, Hale K, Lee M, Walsh T, Owens K, et al. Tamoxifen and breast cancer incidence among women with inherited mutations in BRCA1 and BRCA2: National Surgical Adjuvant Breast and Bowel Project (NSABP-P1) Breast Cancer
Prevention Trial. JAMA. 2001;286(18):2251-6. https://doi. org/10.1001/jama.286.18.2251

29. PhillipsKA,MilneRL,RookusMA,DalyMB,AntoniouAC,PeockS, et al. Tamoxifen and risk of contralateral breast cancer for BRCA1 and BRCA2 mutation carriers. J Clin Oncol. 2013;31(25):3091-99. https://dx.doi.org/10.1200\%2FJCO.2012.47.8313

30. Ludwig KK, Neuner J, Butler A, Geurts JL, Kong AL. Risk reduction and survival benefit of prophylactic surgery in BRCA mutation carriers, a systematic review. Am J Surg. 2016;212(4):660-9. Risk reduction and survival benefit of prophylactic surgery in BRCA mutation carriers, a systematic review. Am J Surg.

31. Heemskerk-Gerritsen BAM, Jager A, Koppert LB, Obdeijn AIM, Collée M, Heijboer HEJ, et al. Survival after bilateral riskreducing mastectomy in healthy BRCA1 and BRCA2 mutation carriers. Breast Cancer Res Treat. 2019;177(3):723-33. https:// doi.org/10.1007/s10549-019-05345-2

32. Boughey JC, Hoskin TL, Degnim AC, Sellers TA, Johnson JL, Kasner MJ, et al. Contralateral prophylactic mastectomy is associated with a survival advantage in high-risk women with a personal history of breast cancer. Ann Surg Oncol. 2010;17(10):2702-9. https://doi.org/10.1245/s10434-010-1136-7

33. Finch APM, Lubinski J, Møller P, Singer CF, Karlan B, Senter $\mathrm{L}$, et al. Impact of Oophorectomy on Cancer Incidence and Mortality in Women With a BRCA1 or BRCA2 Mutation. J Clin Oncol. 2014;32(15):1547-53. https://dx.doi. org/10.1200\%2FJCO.2013.53.2820

34. Kotsopoulos J, Gronwald J, Karlan BY, Huzarski T, Tung $\mathrm{N}$, Moller $\mathrm{P}$, et al. Hormone replacement therapy after oophorectomy and breast cancer risk among BRCA1 mutation carriers. JAMA Oncol. 2018;4(8):1059-65. https://doi. org/10.1001/jamaoncol.2018.0211

35. Tung NM, Boughey JC, Pierce LJ, Robson ME, Bedrosian I, Dietz JR, et al. Management of Hereditary Breast Cancer: American Society of Clinical Oncology, American Society for Radiation Oncology, and Society of Surgical Oncology Guideline. J Clin Oncol. 2020;38(18):2080-106. https://doi.org/10.1200/jco.20.00299

36. Metcalfe K, Gershman S, Ghadirian P, Lynch HT, Snider C, Tung N, et al. Contralateral mastectomy and survival after breast cancer in carriers of BRCA1 and BRCA2 mutations: Retrospective analysis. BMJ. 2014;348:g226. https://doi. org/10.1136/bmj.g226

37. van den Broek AJ, Schmidt MK, van't Veer LJ, Oldenburg HAS, Rutgers EJ, Russell NS, et al. Prognostic impact of breastconserving therapy versus mastectomy of BRCA1/2 mutation carriers compared with noncarriers in a consecutive series of young breast cancer patients. Ann Surg. 2019;270(2):364-72. https://doi.org/10.1097/sla.0000000000002804

38. Park H, Choi DH, Noh JM, Huh SJ, Park W, Nam SJ, et al. Acute skin toxicity in Korean breast cancer patients carrying BRCA mutations. Int J Radiat Biol. 2014;90(1):90-4. https://doi.org/10. 3109/09553002.2013.835504

39. Pierce LJ, Strawderman M, Narod SA, Oliviotto AE, Eisen A, Dawson $\mathrm{L}$, et al. Effect of radiotherapy after breast conserving treatment in women with breast cancer and germline BRCA1/2 mutations. J Clin Oncol. 2000;18(19):3360-9. https:// doi.org/10.1200/jco.2000.18.19.3360 
40. Robson M, Im SA, Senkus E, Xu B, Domchek SM, Masuda N, et al. Olaparib for Metastatic Breast Cancer in Patients with a Germline BRCA Mutation. N Engl J Med. 2017;377(6):523-33. https://doi.org/10.1056/nejmoa1706450

41. Litton JK, Rugo HS, Ettl J, Hurvitz SA, Gonçalves A, Lee KH, et al. Talazoparib in Patients with Advanced Breast Cancer and a Germline BRCA Mutation. N Engl J Med. 2018;379(8):75363. https://doi.org/10.1056/nejmoa1802905

42. Achatz MI, Caleffi M, Guindalini R, Marques RM, Rodrigues AN, Prolla PA. Recommendations for Advancing the Diagnosis and Management of Hereditary Breast and Ovarian Cancer in Brazil. JCO Glob Oncol. 2020;6:439-52. https://doi.org/10.1200/ jgo.19.00170

43. Chompret A, Brugieres L, Ronsin M, Gardes M, Freichey FD, Abel A, et al. P53 germline mutations in childhood cancers and cancer risk for carrier individuals. BrJ Cancer. 2000;82(12):193237. https://dx.doi.org/10.1054\%2Fbjoc.2000.1167

44. Petitjean A, Mathe E, Kato S, Ishioka C, Tavtigian SV, Hainaut P, et al. Impact of mutant p53 functional properties on TP53 mutation patterns and tumor phenotype: lessons from recent developments in the IARC TP53 database. Hum Mutat. 2007;28(6):622-9. https://doi.org/10.1002/humu.20495

45. Olivier M, Goldgar DE, Sodha N, Ohgaki H, Kleihues P, Hainaut P, et al. Li-Fraumeni and related syndromes: correlation between tumor type, family structure, and TP53 genotype. Cancer Res. 2003;63(20):6643-50.

46. Achatz MIW, Olivier M, Le Calvez F, Martel-Planche G, Lopes A, Rossi BM, et al. The TP53 mutation, R337H, is associated with Li-Fraumeni and Li-Fraumeni-like syndromes in Brazilian families. Cancer Lett. 2007;245(1-2):96-102. https:// doi.org/10.1016/j.canlet.2005.12.039

47. Limacher JM, Frebourg T, Natarajan-Ame S, Bergerat JP. Two metachronous tumors in the radiotherapy fields of a patient with Li-Fraumeni syndrome. Int J Cancer. 2001;96(4):238-42. https://doi.org/10.1002/ijc.1021

48. Henry E, Villalobos V, Million L, Jensen KC, West R, Ganjoo $\mathrm{K}$, et al. Chest wall leiomyosarcoma after breast-conservative therapy for early-stage breast cancer in a young woman with LiFraumeni syndrome. J Natl Compr Canc Netw. 2012;10(8):93942. https://doi.org/10.6004/jnccn.2012.0097

49. Kratz CP, Achatz MI, Brugières L, Frebourg T, Garber JE, Greer MLC, et al. Cancer Screening Recommendations for Individuals with Li-Fraumeni Syndrome. Clin Cancer Res. 2017;23(11):e38-e45. https://doi.org/10.1158/1078-0432.ccr-17-0408

50. Tan MH, Mester J, Peterson C, Yang Y, Chen JL, Rybicki LA, et al. A Clinical Scoring System for Selection of Patients for PTEN Mutation Testing Is Proposed on the Basis of a Prospective Study of 3042 Probands. Am J Hum Genet. 2011;88(1):42-56. https://dx.doi.org/10.1016\%2Fj.ajhg.2010.11.013

51. Zbuk KM, Eng C. Cancer phenomics: RET and PTEN as illustrative models. Nat Rev Cancer. 2007;7(1):35-45. https:// doi.org/10.1038/nrc2037
52. Takeichi M. Cadherin cell adhesion receptors as a morphogenetic regulator. Science. 1991;251(5000):1451-5. https://doi.org/10.1126/science.2006419

53. Pharoah PD, Guilford P, Caldas C. Incidence of gastric cancer and breast cancer in $\mathrm{CDH} 1$ (E-cadherin) mutation carriers from hereditary diffuse gastric cancer families. Gastroenterology. 2001;121(6):1348-53. https://doi.org/10.1053/gast.2001.29611

54. Figueiredo J, Melo S, Carneiro P, Moreira AM, Fernandes MS, Ribeiro AS, et al. Clinical spectrum and pleiotropic nature of CDH1 germline mutations. J Med Genet. 2019;56(4):199-208. https://doi.org/10.1136/jmedgenet-2018-105807

55. National Comprehensive Cancer Network. Genetic/Familial High-Risk Assessment: Breast and Ovarian [Internet]. National Comprehensive Cancer Network; 2020 [accessed on May 27, 2020]. Available at: https://www.nccn.org/store/login/ login.aspx?ReturnURL=https://www.nccn.org/professionals/ physician_gls/pdf/genetics_bop.pdf

56. Cisco RM, Ford JM, Norton JA. Hereditary diffuse gastric cancer: implications of genetic testing for screening and prophylactic surgery. Cancer. 2008;113(7 Suppl.):1850-6. Hereditary diffuse gastric cancer: implications of genetic testing for screening and prophylactic surgery. Cancer.

57. Hearle N, Schumacher V, Menko FH, Olschwang S, Boardman LA, Gille JJP, et al. Frequency and spectrum of cancers in the Peutz-Jeghers syndrome. Clin Cancer Res. 2006;12(10):320915. https://doi.org/10.1158/1078-0432.ccr-06-0083

58. Giardiello FM, Trimbath JD. Peutz-Jeghers syndrome and management recommendations. Clin Gastroenterol Hepatol. 2006;4(4):408-15. https://doi.org/10.1016/j.cgh.2005.11.005

59. Syngal S, Brand RE, Church JM, Giardiello FM, Hampel HL, Burt RW, et al. ACG clinical guideline: Genetic testing and management of hereditary gastrointestinal cancer syndromes. Am J Gastroenterol. 2015;110(2):223-62. https:// dx.doi.org/10.1038\%2Fajg.2014.435

60. Shiovitz S, Korde LA. Genetics of breast cancer: a topic in evolution. Ann Oncol. 2015;26(7):1291-9. https://dx.doi. org/10.1093\%2Fannonc\%2Fmdv022

61. Wendt C, Margolin S. Identifying breast cancer susceptibility genes - a review of the genetic bachground in familial breast cancer. Acta Oncol. 2019;58(2):135-46. https://doi.org/10.1080/ 0284186x.2018.1529428

62. Antoniou AC, Foulkes WD, Tischkowitz M. Breast-cancer risk in families with mutations in PALB2. N Engl J Med. 2014;371(17):1651-2. https://doi.org/10.1056/nejmc1410673

63. Easton DF, Pharoah PDP, Antoniou AC, Tischkowitz M, Tavtigian SV, Nathanson KL, et al. Gene-panel sequencing and the prediction of breast-cancer risk. N Engl J Med. 2015;372:2243-57. https://doi.org/10.1056/NEJMsr1501341

64. Yurgelun MB, Hiller E, Garber JE. Population-wide screening for germline BRCA1 and BRCA2 mutations: Too much of a good thing? J Clin Oncol. 2015;33(28):3092-5. https://doi. org/10.1200/jco.2015.60.8596 